\title{
La matanza del Jueves de Corpus. Fotografía y memoria
}

Carlos Mendoza Aupetit

Canal 6 de Julio/CUEC

Universidad Nacional Autónoma de México, México

monteferroo2@gmail.com

Alberto del Castillo Troncoso, La matanza del jueves de corpus. Fotografía y memoria, México, INEHRM/Memórica/Secretaría de Cultura, 2021.

La matanza del Jueves de Corpus. El método de la tomografía

Es falso que una imagen valga más que mil palabras, como se ha dicho hasta el cansancio, y esto lo sabe muy bien el doctor Alberto del Castillo Troncoso. Él entiende de sobra que, en todo caso, las imágenes suelen alcanzar su mayor poder informativo y de interpretación al conjugarse con las palabras.

Vale recordar en este punto al teórico del cine documental, Bill Nichols, quien afirma en uno de sus textos que "en el mejor de los casos las imágenes pueden ilustrar una cuestión que a la larga tendrá que recurrir a las palabras para exponer su significado e implicaciones", una premisa que ya ratificaba constantemente Del Castillo en su libro titulado, Ensayo sobre el movimiento estudiantil de 1968. La fotografía y la construcción de un imaginario, publicado en coedición por el Instituto Mora y la UNAM, y ahora lo hace nuevamente, con esmero, en su magnífico trabajo, La Matanza del Jueves de Corpus. Fotografía y Memoria, a cargo del INEHRM, la Secretaría de Cultura y Memórica.

$\mathrm{Y}$ es que la simple sentencia de Nichols, referida al empleo de intertítulos y, posteriormente, de la voz en off, en el cine documental, constituye un tema que viene de lejos, pues uno de sus antecedentes más remotos está en los manuscritos

\footnotetext{
(c) (1) (8)

4.0 Internacional
}

Secuencia. Reseñas, 2021

http://secuencia.mora.edu.mx

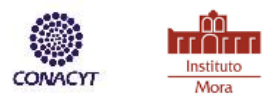


ilustrados del período romántico, que tras una aventura de largos siglos desembocaría en ciertas prácticas del periodismo actual. Un quehacer qué a través de la caricatura y el recurso conocido como "pie de foto", agrega las palabras necesarias para dotar de todo su sentido a dibujos o fotografías, frecuentemente incapaces de invocar el contexto en que fueron producidas y las implicaciones que tienen en relación con el suceso del que forman parte.

Es obvio, pues, que no intento presentar al autor de La Matanza del Jueves de Corpus como el descubridor de la fórmula que permitió reunir virtuosamente lo visual con lo escrito, ni de haber creado ese lenguaje bimodal, pero sí de hacer de él la piedra angular de un quehacer investigativo modélico y llevarlo a cabo con tino y sobriedad, toda vez que una de las mayores cualidades del trabajo que hoy nos reúne, es la lucidez con que se engranan íconos y palabras, con base en una acertada estrategia discursiva. No obstante, antes de ahondar en esos pormenores del trabajo que comentamos, es necesario referirse a éste en perspectiva, empezar por el principio.

La Matanza del Jueves de Corpus. Fotografía y Memoria, es un libro que cuenta a detalle la historia de la represión a los manifestantes estudiantiles que salieron a la calle en las inmediaciones de la Escuela Normal Superior de San Cosme, en el Distrito Federal, la tarde del 10 de junio de 1971. Es el producto de una investigación concebida para reunir y analizar la imagen fotográfica y su relación con la información escrita, principalmente en medios impresos. Una muy laboriosa y compleja tarea acompañada de la revisión crítica y exhaustiva que el autor hace de su objeto de estudio en cuatro niveles:

1. Las fotografías publicadas inmediatamente en diarios y revistas, incluidas las notas acerca de las repercusiones del ataque de los paramilitares a fotógrafos de medios oficialistas.

2. El trabajo de los fotógrafos independientes Enrique Bordes Mangel y Armando Lenin Salgado.

3. Las fotografías que obran en los archivos de los servicios de seguridad e inteligencia del Estado. 
4. Las fotografías publicadas en la prensa sobre los actos conmemorativos que han contribuido a crear la memoria colectiva del llamado Jueves de Corpus, especialmente de las marchas que recuerdan lo ocurrido y de otros hechos relacionados con éste, que tuvieron lugar a lo largo de cincuenta años.

Vale destacar que estos cuatro niveles, cuidadosamente articulados mediante una narración que cruza a lo largo del texto bimodal, aporta información indispensable, sitúa el contexto político y social, ofrece valiosas reflexiones, anécdotas y digresiones del autor. Una tarea realizada mediante una afortunada mezcla de las estrategias discursivas de la narración y la descripción -esta última generalmente usada para referirse al contenido de las fotografías expuestas- que no deja cabos sueltos de la aparentemente enredada trama de lo ocurrido. Se trata de un conjunto de cualidades, a las que se debe agregar la valiosísima bibliografía que resultó del tenaz y acucioso trabajo del autor. Así, los cuatro subtemas en que se divide este trabajo son tratados con idéntica minuciosidad, con el mismo afán por hacer un recuento y análisis exhaustivo que solo difiere, debido a los volúmenes de material que arroja cada uno de estos aspectos. Por lo que es necesario destacar como parte fundamental del método del autor, la disciplina que lo lleva a agotar, literalmente, lo que parece ser el total de la documentación existente, de cada vertiente de su tema.

Considero importante destacar, como ejemplo de lo anterior, la labor que hay detrás del cuarto nivel del texto, titulado "La construcción de la memoria", que a lo largo de un centenar de páginas explora fotografías y notas de los eventos de la conmemoración de la matanza, en las cinco décadas que le siguieron. De actos políticos en principio casi insignificantes, debido al clima de represión que prevalecía, y posteriormente, a partir de 1977, a través principalmente de manifestaciones multitudinarias y combativas que reunían lo mismo a ex líderes del 68 y veteranos del 10 de junio, que a jóvenes estudiantes. Por ese camino, Del Castillo nos narra la historia particular de estas protestas, dentro de la historia general de la matanza del 10 de junio. Un largo trayecto de rituales cívicos que discurre en caminatas masivas de protesta de una izquierda marginal y radicalizada. Un conjunto de protestas celebradas anualmente, que tendrán continuación en las 
realizadas ya al cobijo de gobiernos de izquierda, a partir de 1998, cuando Cuauhtémoc Cárdenas gobernaba la capital de la República, con lo que se instalaba un nuevo escenario para la evocación de este acontecimiento, que tendrá un momento significativo con la develación de una placa conmemorativa en la estación del Metro Normal, el 10 de junio de 2001, por el entonces nuevo jefe de gobierno del Distrito Federal, Andrés Manuel López Obrador. Tal ceremonia tuvo lugar al tiempo que la Fiscalía Especial para Movimientos Políticos y Sociales del Pasado (FEMOSSP), creada por Vicente Fox, protagonizaba un frustrado intento por llevar ante la justicia a los responsables de la matanza, lo que más tarde dará lugar a recurrentes actos de protesta ante el domicilio del expresidente Luis Echeverría.

El completo recorrido que Del Castillo hace por ese evento tradicional es puesto al servicio del conocimiento de lo acontecido, de su historia y de la preservación de la memoria de éste, un trabajo cuyo equilibrio nos remite a Beatriz Sarlo, quien en su libro Tiempo pasado, afirma: "El pasado es siempre conflictivo. A él se refieren, en competencia, la memoria y la historia, porque la historia no puede creerle siempre a la memoria, y la memoria desconfía de una reconstrucción que no ponga en sus centros los derechos del recuerdo (derechos de vida, de justicia y de subjetividad)" (p. 9).

Vale subrayar, por otra parte, que, en el minucioso trabajo crítico del autor, registra, entre otras cosas, el relevo generacional en el gremio de los fotoreporteros, un conjunto de nuevas miradas, entre las que destaca Marco Antonio Cruz junto con Fabrizio León, Elsa Medina, Raúl Ortega y Antonio López Pantoja, que aún alternaban con otros trabajadores de la lente quienes, literalmente, habían hecho historia, como los Hermanos Mayo, Metinides y Reyes Zurita. Un giro que trajo cambios sensibles como el propuesto por el diario La Jornada, que durante años dio mayor relevancia en sus páginas al trabajo de sus propios fotógrafos, al que incluso reconocía frecuentemente, además de cualidades informativas, las artísticas y, en algunos casos, el estatus de ensayos visuales. En ese sentido, la combinación de recursos y estrategias discursivas que hace Del Castillo, da por resultado un trabajo que oscila entre la amenidad de un relato histórico y el rigor que demanda la investigación académica, aderezado con apuntes personales. 
Por eso se puede afirmar que este trabajo no es una radiografía del 10 de junio de 1971, obviando la consabida metáfora, sino una tomografía de ese episodio de terrorismo de Estado, puesto que es la suma de diversas radiografías, captadas desde distintos ángulos, que ofrecen una visión periférica de los componentes de este, posteriormente procesados para su interpretación.

Los variados ángulos del conflicto que el autor propone terminan por ofrecer una suerte de diagnóstico integral y sistémico: un episodio de terrorismo de Estado malamente encubierto, la fotografía y la construcción de la memoria de esa masacre.

No obstante, la profunda y ordenada excavación realizada por el autor para llegar al fondo de sus temas centrales y la construcción de las galerías que interconectan a éstos, deja al descubierto grietas y hendiduras por donde asoman vetas menos exploradas. Un conjunto de temas llamados a nutrir o inaugurar nuevas indagaciones en temas probables como la continuidad de la paramilitarización hasta nuestros días; las camaleónicas posturas de los más notorios intelectuales mexicanos en situaciones álgidas, o la dignidad profesional, semi oculta, de reporteros gráficos que trabajaban para los medios sometidos.

Debo señalar, por otra parte, que, pese a los abundantes puntos de concordancia con el trabajo del autor, discrepo un tanto del énfasis que pone en Luis Echeverría como figura central de la masacre, no por su falta de perversidad y méritos represivos, que los tiene de sobra, sino porque se trata de un espécimen más de los miles que portan el ADN autoritario, que caracterizó - ¿̇o caracteriza? - al partido de Estado. Ese rasgo genético inconfundible de un régimen cuyas proezas violentas arrancan en tiempos inmemoriales con personajes legendarios como Elías Calles, Alemán, López Mateos- y se siguió nutriendo hasta apenas ayer, con los crímenes de mandatarios como Felipe Calderón (priísta por contagio) y Enrique Peña (priísta de aparador), pasando por Rosario Robles (maoísta conversa), que dejaron constancia de que el legado del PRI, sea por herencia genética o imitación pasa por el autoritarismo practicante. Disiento también, en menor medida, de la ponderación que el autor hace del filme Roma de Alfonso Cuarón, en el que Los Halcones y el 10 de junio son incluidos, a mi entender, como un condimento necesario para dotarlo de corrección política. 
Sin embargo, y por encima de tales matices, debemos reconocer en la trayectoria de Alberto del Castillo su significativa contribución al reconocimiento y validación de la imagen fotográfica y cinematográfica en el ámbito académico del país, antes rígidamente adherido a una visión logocentrista, que regateaba a la imagen fotográfica, fija o en movimiento, todo valor epistémico. Resistencia que se fue venciendo lentamente a través del trabajo de investigadores como Aurelio de los Reyes, Ricardo Pérez Monfort, Carlos Martínez Assad, Lourdes Roca y el propio Del Castillo, entre otros.

También es obligado reconocer que La matanza de Jueves de Corpus puede ser entendido también como un libro de historia, que cuenta de manera confiable y documentada los hechos del 10 de junio, lo que ya representaría un mérito singular; pero también como un libro que aborda ese tema desde la compilación y el análisis de la imagen fotográfica y del periodismo de cada momento histórico.

Sin embargo, y más allá de dichas cualidades, este escrito permite asomarse a indagaciones diversas y curiosas. Por ejemplo el comentario que exhibe los notorios reacomodos del poeta Octavio Paz ante la matanza, y su decisión de sumarse, a final de cuentas, a la postura de Luis Echeverría, o el modo que tiene el autor para ponderar, desde la más sincera admiración, a fotógrafos como Rodrigo Moya, Nacho López, Enrique Bordes Mangel y Armando Salgado, o la oportunidad que nos brinda de conocer la imagen del documentalista polaco, Anthony Halik, entonces al servicio de la cadena estadunidense $N B C$, captado minutos antes de ser apaleado por Los Halcones y registrar, entre peripecias, la mayor parte de la imágenes cinematográficas que se conocen del llamado Halconazo.

Concluyo este comentario con dos apuntes sobre los apartados finales de la obra. El titulado "Consideraciones finales" es una breve recapitulación acerca de su exhaustivo trabajo, que recurre a los procedimientos de la historia en tiempo presente y su zigzagueante relación con la construcción de la memoria. Y también me refiero al epílogo, titulado "La última fotografía pública de Luis Echeverría”, en el que nuestro autor explora esa imagen, ya icónica, con el instrumental crítico que utiliza con excelencia, pero también con el corazón, lo que lo lleva a hacer una 


\section{Carlos Mendoza Aupetit}

reflexión, con fuerte carga opinativa, en la que asoma su postura, no exenta de pasión, cosa que se agradece.

Con todo, parece necesario insistir, por último, en la que probablemente es la mayor fortaleza de la obra. Me refiero, una vez más, al procedimiento de la tomografía, aplicado a la imagen fotográfica de un acontecimiento político atroz y sus variados contextos, un método que penetra en la médula de ese suceso y parece haber patentado Alberto del Castillo Troncoso. 